\title{
Is Swedish Research in Economic History Internationally Integrated?
}

First version: October 10, 2004

This version: August 12, 2005.

\author{
Daniel Waldenström \\ Department of Economics \\ Stockholm School of Economics \\ Box 6501, SE-11383 Stockholm \\ Daniel.Waldenstrom@hhs.se
}

\begin{abstract}
This paper presents empirical evidence of the international integration of Swedish economic historians. Contrary to the claims of a recent national evaluation of the discipline, the Swedish shares of international publications and conference presentations are robustly below available cross-country and cross-discipline benchmarks. Also considering levels of research inputs, the relative underperformance of the Swedish field is alarming. Four main explanations to this situation are forwarded: 1) Being among the largest economic history communities in the world, Sweden has become self-sufficient and almost independent of the international arena. 2) The dominating research language is Swedish. 3) The dominating publication format is monographs (in Swedish). 4) Swedish economic historians are reluctant to use modern economic theories and statistical analysis to complement the traditionally dominant qualitative research methods.
\end{abstract}

JEL: A12, A20, N00, N01

Keywords: Economic history, Historical economics, Methodology, Research policy, Bibliometrics, Bibliography 


\section{Introduction}

During 2002-2003 a commission appointed by the Swedish Agency for Higher Education (Högskoleverket) conducted a comprehensive evaluation of economic history in Sweden. ${ }^{1}$ Its primary objective was to audit the quality of the educational programs at Swedish universities, but the evaluation commission also made several judgments about the quality of the research in the discipline. It described the research in highly positive terms as being of "high international standards" as shown by the "very high activity at international conferences and in international publications since the 1960 's". ${ }^{2}$ This favorable characterization influenced the Agency's official comments and the University Chancellor's final statement about the overall status of the discipline. ${ }^{3}$

A closer look at the evidence underlying the claims of the commission revealed, however, an almost complete lack of empirical backing of any kind. The commission presents no compilations of international publications or cites other studies that contain such. While this lack of empirical evidence is remarkable, any conclusions from that about the true output levels cannot be drawn. These unfounded claims are though cited uncritically by the highest public authority for the quality supervision of Swedish university education and this easily make them the "working truth" among academic scholars, students and policymakers for a long time.

The purpose of this study is to fill this information gap by presenting comprehensive data on the international publication and conference activities of Swedish economic historians from 1970 to the present. To my knowledge, this evidence has never before been systematically compiled or analyzed before. Following the explicit focus in the national evaluation, I only examine the output Swedish economic historians active at Swedish economic history departments, leaving out the Swedish researchers active in other disciplines (predominantly in economics) that have published in international economic history journals and books. My analysis starts with a count of article authorship in eighteen of the largest international economic history journals, covering more than 9200 articles, which consti-

\footnotetext{
${ }^{1}$ The evaluation commission consisted of the following Nordic scholars: Lars Engwall (chair), Per Boje, Kristine Bruland, Riita Hjerppe, Hans Christian Johansen, Eva Lindgren and Daniel Nyberg.

${ }^{2}$ This statement occurs on several places in the report. See Utvärdering av ämnet ekonomisk historia vid svenska universitet, Stockholm: Swedish Agency for Higher Education (Högskoleverket), 2003, pp. 5f, 34f, 81, downloadable at http://www.hsv.se/sv/FileServlet/doc/1195/0311R.pdf (2004-11-27).

${ }^{3}$ Utvärdering av ämnet ekonomisk historia pp. 5 and 9.
} 
tute the bulk of (mostly) peer-reviewed international economic history research. Publication in any of these journals is therefore the single most important evidence of internationally viable research production. To broaden the assessment, I also examine journal publications in other fields such as history, economics, sociology, political sciences as well as the complete list of all international publications (journal articles, books and chapters in books) by the 40 currently active professors and associate professors of economic history at Swedish universities. Conference participation is examined by checking the programs of 23 large international economic history conferences in recent years.

To put the observed output shares into perspective, I compare them with other countries, especially the Nordic ones and the U.K. and the U.S., and with other Swedish academic disciplines. Most of these comparisons are based on newly assembled information due to the general lack of benchmark data from previous studies.

The remainder of the paper is organized as follows. Section 2 discusses the methods used, data and some important methodological problems. Sections 3 and 4 present the findings for publications and conference attendance, respectively. In section 5, all results are related to various benchmarks. Section 6 offers some explanations to the observed patterns. Section 7 concludes.

\section{Method, data and problems}

The overall empirical method used in this study is counting the number of appearances of Swedish economic historians in either various international journals and books or as presenters at conferences. These numbers are then compared with their equivalents for other Nordic and foreign economic historians or scholars in other academic disciplines. Citations and other impact-related data are left out of the analysis since they are only available for a small amount of publications in the field.

To qualify the analyses, I classify the journals and books in groups to roughly distinguish between higher and lower ranked publications. The economic history journals are divided into one "top-4" group and one "others" group based on available rankings and listings (see further below). Books and book chapters are similarly classified in three groups: "ranked international", "other international" and "Swedish" (mostly university- 
associated publishers). I define the first group generously by including publications at Cambridge, Oxford and MIT University Presses, Edward Elgar (not reprints in the "Reference Collection" series), Routledge, Sage, Kluwer, Macmillan and Springer. ${ }^{4}$ Given the broad subject nature of economic history research, I also broaden the journal coverage by including several journals from other academic disciplines in human, natural and social sciences. I define journal articles as including shorter papers and comments but not debate articles, conference proceedings, book reviews or editorial notes as articles. I also separate between non-invited and invited articles, which are basically two different kinds of publications. ${ }^{5}$ Co-authorship is weighted when possible by giving an author $1 / n$ publications for articles with $n-1$ co-authors. ${ }^{6}$ The Appendix lists all journal articles (both invited and non-invited) by Swedish and Nordic economic historians for the period 19702004.

Data on international journal publications come to a large extent from is the well-known Science Citation Index, Social Sciences Citation Index (SSCI) and Arts and Humanities Citation Index. These databases contain primarily English-written journals and cover the period since 1986. Unfortunately they do not cover most economic history journals, why the bulk of my data (including books and book chapters by Swedish faculty members) are collected manually from other disparate sources. ${ }^{7}$

Some problems with the analysis need special attention. First, it is well-known that most journal article databases are dominated by English-written publications largely ignoring the sizeable literature in other languages (e.g., French or German). ${ }^{8}$ Although this study indeed predominantly examines publications in English, the journal sample actually contains several journals that either belong to a clearly non-English sphere or are simply not

\footnotetext{
${ }^{4}$ These were the publication houses that appeared in the Swedish data, but naturally there are other university presses and private publishers belonging to the high-ranked group, but Swedes never published there.

${ }^{5}$ Invited articles in special issues can at times be preceded by more restrictive and critical selection procedure than non-invited articles in normal issues, but the opposite is arguably the more typical case.

${ }^{6}$ See, e.g., Lindqvist, Tobias, "Nationalekonomisk forskning i Sverige - publiceringar och rankning av forskare", Ekonomisk Debatt, vol. XXXI, 2003:3, 21-32.

${ }^{7}$ Sources were Econlit (EBSCOhost), LIBRIS (the Swedish library catalogue), homepages of journals, departments and scholars as well as the internet sites of Stuart Jenks and Dieter Rübsamen (eds.) Magazine stacks at http://www.phil.uni-erlangen.de/ p $1 \mathrm{ges} / \mathrm{zfhm} / \mathrm{zfhm}$ na.html and Istituto internazionale di storia economica "Francesco Datini" at http:/www.istitutodatini.it/biblio/riviste/htm/elenco.htm (both on 200503-04).

${ }^{8}$ See, e.g., Sandelin, Bo and Nikias Sarafoglou "Language and scientific publication statistics: A note", Language Problems \& Language Planning, vol. XXVII, 2004:1, 1-10.
} 
written in English. ${ }^{9}$ Besides, nothing in my coverage of all non-Swedish publications of Swedish higher faculty (section 3.4 below) indicates a structural propensity to publish relatively more in non-English foreign languages. Finally, recent bibliometric research shows that scholars from small countries with English as second language (i.e., Nordic scholars) are relatively well represented in the English speaking literature, both in science and many social sciences. ${ }^{10}$

A second problem concerns the dominant focus on journal articles, especially in databases such as SSCI, while books and chapters in books receive much less attention. According to recent estimates by Diana Hicks, books may comprise about $50 \%$ of the relevant literature in social and human sciences. This suggests severe sample selection biases when evaluating total output based on only article sources. ${ }^{11}$ In my study, I try to circumvent parts of this problem by examining the all publications of the higher faculty in Sweden. Moreover, if publication patterns within disciplines are the same across countries, my output shares for economic history are not affected by this problem at all. Hicks and others also note that the increasing globalization of social science research steadily increases the share of articles over books, which means that the articles databases become more and more representative. ${ }^{12}$

Thirdly, merely presenting output numbers and shares without linking them to impactrelated information or measures of inputs (number of faculty, size of research budgets etc) makes interpretation difficult. Due to a lack of data for all journals outside the Thomson ISI universe this problem cannot be solved without massive database building efforts. I do incorporate some reference points in terms of publications by foreign economic historians and other Swedish scholars and section 5 also presents some tentative input estimates of both Swedish economic history and economics. One must though bear

\footnotetext{
${ }^{9}$ As for economic history journals, both Journal of European Economic History and History of Economic Ideas are published in Italy and clearly dominated by Italian authors. The history journal sample (from SSCI) contains the French Mouvement Social and the German Zeitgeschichte.

${ }^{10}$ See Sandelin and Sarafoglou, Language and scientific publication, and Ingwersen, Peter "The international viability and citation impact of Scandinavian research articles in selected Social Science fields: The decay of a myth", Scientometrics, vol. XLIX, 2000:1, 39-61.

${ }^{11}$ Hicks, Diana "The difficulty of achieving full coverage of international social science literature and the bibliometric consequences", Scientometrics, vol. XL, 1999:2, 193-215.

${ }^{12}$ This is emphasized by Ingwersen, The international viability, and Kyvik, Svein "Changing trends in publishing behavior among university faculty, 1980-2000”, Scientometrics, vol. LVIII, 2003:1, 35-48.
} 
in mind that this study is a first attempt to explore and analyze Swedish and international research production in economic history.

The fourth problem is to adequately evaluate past research carried out under different historical contexts and institutional prerequisites. In the Swedish case, much of the research in economic history was conducted under large-scale projects run by a few leading professors. These projects primarily aimed at exploring central themes and institutions in Sweden's industrialization such as the iron industry (in the so-called "Fagersta project") or the standard of living (in the "the Welfare project"). ${ }^{13}$ Counting the number of international journal articles produced by these projects could be a problematic evaluation method if these projects never aimed at publishing abroad at all. On the other hand, already the founding father of Swedish economic history, Eli F. Heckscher, published actively in international economics and economic history journals in the 1930's and 1940's. Judging from his undisputed reputation among past and present economic historians that was hardly a neglected or disrespected publication alternative.

\section{International publications by Swedish economic historians}

\subsection{Articles in the "top-4" economic history journals}

Among the most important arenas for international economic history publications are the large international journals with a general subject focus. Based on the available citationbased journal rankings I have selected the following four journals with such focus for a group called "top-4": Journal of Economic History (JEH), run by the Economic History Association in the U.S.; Explorations in Economic History (EEH), published by Elsevier; Economic History Review (EHR) run by the Economic History Society in the U.K. and European Review of Economic History (EREH), run by the European Historical Economics Society. ${ }^{14}$ The first three have long publishing traditions and always appear in the top group of economic history journals. Several persons have advocated EREH as a strong contestant in recent years. Since it is also publishing all sub-fields I include it in this top group as well. Note that the selection relies on an economics-based ranking and

\footnotetext{
${ }^{13}$ These and other projects are described in, e.g., Hildebrand, Karl-Gustaf "Swedish economic history before the 1980s", Scandinavian Economic History Review, vol. XXXVIII, 1990:2, 31-40, and Olsson, Ulf, "Fluctuat nec mergitur: Economic history in Sweden at the turn of the century 2000", Scandinavian Economic History Review, vol. L, 2002:3, 68-82.

${ }^{14}$ Kalaitzidakis, Pantelis, Theofanis P. Mamuneas and Thanasis Stengos, "Rankings of academic journals and institutions in economics", Journal of the European Economic Association vol. I, 2003:6, 1346-1366.
} 
using a more history-related ranking (if such one exists) could well include other journals (but also most of the ones in the "top-4"). ${ }^{15}$

The results for Sweden and the other Nordic countries are shown in Figure 1 and 2 and Table 1 and 2. At a first glimpse, the absence of publications in the 1970's and 1980's for all Nordic countries and also the 1990's for Sweden is remarkable. Over the entire period since 1970 Swedes wrote 8.33 of the more than 3,800 non-invited articles in the “top-4" journals, representing $0.22 \%$. Including invited articles does not change this result (the share is $0.24 \%$ ). The other Nordic countries, primarily Denmark and Norway, wrote $19(0.5 \%)$ non-invited articles. The situation improved in the late 1990's, particularly thanks to the launching of EREH. Swedish output shares in 1998-2004 increased to $1.07 \%(1.23 \%)$ whereas other Nordic scholars wrote $1.9 \%$ (not disclosed in the table).

Table 2 presents an explicit comparison for many Western countries for 1986-2004 both counting the "top-4" shares and when the Business History Review and Business History (also in SSCI) are also included. Only for the "top-4", the Swedish share is $0.6 \%$ whereas Denmark (0.5\%), Norway (0.3\%) and Finland (0.1\%) have smaller shares. Anglo-Saxon countries, particularly the U.S. the U.K., vastly outperform all others while continental Europe lags behind. Adding the business history journals flattens the distribution somewhat, but not significantly. Overall, these figures confirm the bibliometric findings of Sandelin and Sarafoglou in their analysis of article authorship and nationality. ${ }^{16}$

\subsection{Swedish articles in other economic history journals}

The Swedish output in other international economic history journals besides the "top-4" group modifies the picture somewhat. The journals are selected to cover most sub-fields, e.g., history of economic ideas, financial history, business history, labor history or transport history, and it is my impression that they represent some of the most well-known journals in all of economic history. Adding journals would perhaps improve the representativity but it would not affect the analysis of the Swedish output shares, if so probably only downward. Included in this group are also the two Scandinavian journals, Scandinavian Economic History Review (SEHR) and Economy and History (EH, ceased in

\footnotetext{
${ }^{15}$ See, e.g., Clausen, Aage R. "Social Science History: Citation Record, 1976-1985", Social Science History, vol. XII, 1988:2, 197-215, showing that the SSCI-based journal rankings of "History of Social Sciences" and "History" contain quite different journals.

${ }^{16}$ Sandelin and Sarafoglou, Language and scientific publication.
} 
1980), which both publish articles from all sub-fields. They were at times explicitly aiming to publish predominantly Nordic research.

Table 1 lists the Swedish output in the eighteen economic history journals in the full sample (including the "top-4") divided on two time periods, 1970-2004 and 1998-2004, and between excluding and including special issues. Over the longer period, Swedes wrote $0.28 \%$ of all non-invited articles and $0.54 \%$ of all articles, disregarding SEHR and EH. In the recent period, these shares were $0.48 \%$ and $0.41 \%$, respectively, which indicates both an increased activity over time but also that many publications before 1998 appeared in special issues. Comparing the output shares in different sub-fields, the history of economic ideas-field seems to be the most active one whereas business history produced above average only over the long period and when including special issues (and not at all when the all-Swedish Business History issue in 1993 is excluded). These results, however, are driven by a change in only a handful of articles which is too small numbers for allowing firm conclusions to be drawn. The two Scandinavian journals represent, as expected, vast outliers both in terms of number and share of Swedish articles. There is no tendency of increasing shares. A somewhat surprising fact, however, is that Swedes only wrote a sixth of all SEHR articles since 1970 despite that roughly $95 \%$ of all SEHR's articles during this period were written by Nordic scholars.

\subsection{Swedish articles in the journals of other disciplines}

Since economic historians often relate their research to various neighboring academic disciplines, it is reasonable to search for articles by Swedish economic historians in other field journals. Specifically, I first examine the 28 journals listed in SSCI's two categories "History" and "History of Social Sciences" between 1986 and 2004. Of the in total 8,543 articles in these journals, $29(0.34 \%)$ were written by Swedish scholars and of them 3 $(0.04 \%)$ were by economic historians. When I add the coverage of four journals in which I knew beforehand that Swedish economic historians had published in, the shares increase to $1.06 \%$ and $0.14 \%$, respectively. ${ }^{17}$ Finally, searching in all other human, natural and social science journals in the entire Thomson ISI databases, I found 20 articles by Swedish economic historians, primarily in economics and medicine journals. These searches clearly shows no signs of relatively large publication activity of Swedish eco-

\footnotetext{
${ }^{17}$ All journals are listed on the Thomson ISI homepage. The four added journals are Continuity and Change, Journal of Family History, Scandinavian Journal of History and Technology and Culture.
} 
nomic historians in journals outside their core field, which I interpret as corroborating the overall findings of the study.

\subsection{International publications by current Swedish professors}

Based on the well-known critique of the journal article-bias prevalent in the SSCI and other similar sources, this section analyzes all international publications (articles as well as books and book chapters) of the 40 current professors and associate professors (docenter) of economic history at Swedish universities. ${ }^{18}$ The group is selected for practical reasons but it naturally is biasing the results to pick the arguably most productive subset of scholars. Table 3 presents the results in aggregate form.

On average, Swedish higher faculty have published 2.35 non-invited, refereed articles throughout their career $(0.90+1.17+0.28)$ which when dividing by the number of years as a graduated scholar (second last row) gives 0.14 articles per year, i.e., one article every 7 years (including articles in SEHR and EH). Adding invited articles in "special issues" does not change this picture (with numbers 2.85 and 0.17 , respectively) and counting medians give even lower numbers. Including non-edited books and chapters in books (including editorial introductions) increases the average annual output per year as Ph.D. to 0.36 (with median 0.24 ), corresponding to one international publication every three (four) years.

The distribution of publications across faculty is significantly skewed towards the top end, meaning that there is a small group of scholars with relatively many publications whereas several have not a single one in some categories. ${ }^{19}$ Furthermore, the parentheses in the right column of Table 3 show that ten scholars (nine when including special issuearticles) have never published an international journal article whereas four of them have never published internationally at all in their entire career!

\section{Swedish activity at international economic history conferences}

Participating in the international research community also concerns attending and organizing conferences. Based on the claim of the evaluation commission that Swedish eco-

\footnotetext{
${ }^{18}$ The sample is based on lists at departmental web pages at the universities of Gothenburg, Linköping, Lund, Stockholm, Umeå, Uppsala and SLU (in Ultuna) and Stockholm School of Economics.

${ }^{19}$ The skewness of the average publications across scholars is 1.848 , corresponding to 4.4 "standard errors of skewness". This confirms that a few large observations at the top end greatly dominate the average.
} 
nomic historians have since long been highly active at international conferences, this section examines conference programs from 23 large international conferences in recent years, counting the number of papers presented by Swedish, (non-Swedish) Nordic and (non-Nordic) European scholars. The sample was selected to span both general meetings and most sub-fields, both in the Americas and Europe. Local Swedish or Nordic meetings were left out since their focus is purely local and attract exclusively domestic scholars presenting in local languages. ${ }^{20}$

According to the results in Table 4, Swedes wrote $31(1.7 \%)$ of the 1811 papers presented but only in 7 of the 23 conferences examined. Scholars from the other Nordic countries presented $2.8 \%$ of all papers and other Europeans presented $50 \%$. This last number also shows that the sample seems fairly balanced between the two continents in terms of participant nationalities. Not disclosed in the table, but still notable, is that almost all Swedish papers were written by faculty, suggesting even lower participation rates for Swedish graduate students which is worrisome in the long run.

\section{Relating the output shares with others and with input levels}

To be able to interpret the descriptive statistics presented thus far as being "high" or "low", one must relate them to some kind of benchmarks or input measures for other countries and/or disciplines. This section does this in two steps: first by comparing them with world output shares of other Swedish disciplines and then by relating them to input levels and comparing both U.K. and U.S. economic history and with Swedish economics. At the first step, recent figures from the Swedish Research Council (Vetenskapsrådet) shows that Swedish scientific publications as shares of the total European output in the 1980's and 90's was for social sciences about 3.5\%-4\%, medicine 7\%-8\% and technology $4 \%-5 \%{ }^{21}$ Economic history was not presented separately, but using the data underlying Tables 1 and 2 shows an increase from $0 \%$ in the 1980's to about $1 \%-2 \%$ in the late 1990's. Another source is Thomson ISI's National Science Indicators which recently presented data on Swedish shares of the world journal articles during 1999-2003. ${ }^{22}$ Swe-

\footnotetext{
${ }^{20}$ Naturally, these local meetings may still fulfill many important duties within the local context. According to Ulf Olsson they attract many scholars (Olsson, Fluctuat nec mergitur, p. 81).

${ }^{21}$ The Swedish share of social science publications by Western European countries were around 4\% during this period, and with the U.S. this should be approximately half that level (Vetenskapsrådet, En stark grundforskning för Sverige.Vetenskapsrådets forskningsstrategi 2005-2008, Stockholm, 2004, pp. 14f).

${ }^{22}$ Downloadable at http://in-cites.com/research/2004/september_6 2004-2.html (2004-12-01).
} 
den's overall share was $2.03 \%$ and among the few disciplines presented separately, immunology had the lead with $3.60 \%$, economics and business had $1.86 \%$, and social sciences had $1.79 \%$. Again economic history was not presented separately, but if one only takes the economic history journals in the SSCI databases also examined here in Table 1 (i.e., BH, BHR, EEH, EHR and JEH), the Swedish share is $0.46 \%$ ( 2 of 432). When considering all economic history journals in Table 1, for the slightly longer period 1998 2004 , the shares are $1.47 \%(1.34 \%)$ or $0.71 \%(0.69 \%)$ depending on whether SEHR and only non-invited (all) articles are counted. Note that none of these studies included human sciences but if that was done their output shares would surely have been even lower than those of economic history. Altogether, when comparing output shares with other countries and scientific disciplines, Swedish economic history is a little or much below the rest of the social science community (but maybe not below many of the human sciences), regardless of time period and sample size.

Turning to research inputs, perhaps the most relevant way to assess relative research performance, I use two of the most relevant measures of inputs: numbers of practicing scholars (with a Ph.D.) and sizes of research funds (in annual budgets) and compare the first of them with U.K. and the U.S. economic history and both with Swedish economics. Swedish economic history has today 126 researchers with a Ph.D. at economic history departments. ${ }^{23}$ The three largest are Uppsala, Lund and Stockholm with about 30 scholars each. At the most recent Swedish national economic history meeting in 2003, 73 papers were presented and about 120 participants were registered. ${ }^{24}$ As for the U.K., I have not found aggregate numbers of all economic historians active at the universities, but looking at the three largest economic history departments, LSE tops with 18 researchers with a Ph.D., followed by Glasgow with 16 and Edinburgh with 14. The EHS conference in 2003 had 76 papers (including student papers) and about registered 200 participants. For the U.S., I counted everyone listing "economic history" as a research interest at the 50 highest ranked economics departments (according to the list in Kalaitzidakis et al.) and found 86 scholars all in all. Similarly, the 2003 EHA meeting had 40 papers (plus 16 poster sessions) and about 220 participants. ${ }^{25}$ Hence, Swedish economic history is almost as large as in the U.K. and U.S. in terms of department size (the three largest economic

\footnotetext{
${ }^{23}$ This listing also includes Linköping University and Stockholm School of Economics.

${ }^{24}$ I thank Joakim Appelquist at Lund University for supplying me with these numbers.

${ }^{25}$ These numbers were collected from the conference organizers directly.
} 
history departments in the world are probably Swedish!) and number of practicing scholars (in seven Swedish departments there are almost 1.5 times more economic historians than in 50 high-ranked U.S. economics departments!). Naturally, some of these numbers are not perfectly comparable (e.g., the meetings vary in frequency). Still, it is my conjecture that if one would take any other European country, in particular another Nordic one, the relative size of Sweden would stand out even stronger.

In a comparison with Swedish economics departments, the picture is roughly the same. There are 254 graduated economists at the large universities, which is about twice as many as equivalent economic historians. Similarly, looking at the research financing received in three large universities in 2003, economic history got about half as much total funding as did economics. ${ }^{26}$ Publicly available publication statistics of international journal articles and non-Swedish working papers from the same departments show that the economics departments produced more than 20 times the output of economic history department, despite enjoying only 2 times the relevant inputs (funding and number of scholars).

\section{Explaining the observed patterns}

So far the paper has dealt with compiling, presenting and comparing empirical data and the main message is that the past international research output of Swedish economic historians is low, both internationally and domestically. The next step is to understand why this arguably undesirable situation has emerged. In the following, I present four explanations that all describe how the incentives of Swedish economic historians are tilted towards writing thick books, free from explicit economic modeling or econometrics, for a local, history-dominated readership. Most of these explanations are coupled with supportive empirical evidence.

a) Abundant research resources: As already argued at length, Swedish economic history is a well-supplied discipline in terms of both absolute and relative financial resources for research. ${ }^{27}$ Ulf Olsson argues that two important explanations for this relative abundance

\footnotetext{
${ }^{26}$ I only found complete statistics for the universities of Stockholm, Umeå and Uppsala. The comparisons concern unweighted averages of the ratio economic history/economics ( 0.45 for internal (i.e., university) funding, 1.80 for external (foundation) funding and 0.60 for total funding).

${ }^{27}$ The extremely successful track record in attracting funding is discussed by the evaluation commission (Utvärdering av ämnet ekonomisk historia, pp. 47-48).
} 
are a long-standing political support from social democratic government authorities throughout sympathizing with this "progressive" academic discipline and also that many economic historians, while trying to survive outside the established core subjects, have developed "considerable expertise in applying for external funds to finance research projects and secure the own livelihood". ${ }^{28}$ In terms of research output, the Swedish relative wealth has allowed the discipline to become nationally self-sufficient and almost independent of the international arena, which has reduced the incentives to publish in the international journals. Secondly, along successes in fund raising comes a diminished competitive pressure within the rich field, which also could lead to lower research output.

b) Writing in a local language (Swedish): Although Swedish history may be most easily written in Swedish, anyone interested in reaching out beyond the tiny group of local scholars is forced to write in a foreign language. Specifically, English has since decades become the undisputed international science language and since Sweden is a "language taker" on the international research market English is arguably the foreign language to use. Writing in English would then imply no extra costs of translation and re-writing when submitting research papers to international conferences and journals. Despite these advantages, however, Swedish economic historians write predominantly in Swedish as evidenced by the dissertations published since 1970, listed in Table 5. The shares of English-written theses have been about a fourth for the whole time and the listings of ongoing dissertation projects indicate no changes on this issue. Comparing with the neighboring economics field, however, it has gone from equal shares of Swedish- and Englishwritten theses in the 1970's to being solely written in English today. ${ }^{29}$ These different degrees of internationalization and the lack of convergence suggest that economic historians both seem uninterested in and provide little incentives for international publications. This persistent lingual provincialism also risks influencing the choice of research topics, analytical tools or even background literature, which in turn creates a narrow domestic focus and an overall depreciated explanatory power. ${ }^{30}$ In a recent study of dissertations in Swedish business administration, education, sociology and psychology, Len-

\footnotetext{
${ }^{28}$ Olsson, Fluctuat nec mergitur, pp. 69, 72.

${ }^{29}$ This development is well-known (Ranki, Sinimaaria and Bo Sandelin, "Internationalization or Americanization of Swedish economics", European Journal of the History of Economic Thought, vol. IV, 1997:2, 248-257.

${ }^{30}$ The overly domestic focus in Swedish economic history text books is criticized by Andersson-Skog, Lena and Olle Krantz, Swedish economic history writing - national self-sufficiency or recognition of the international context?, Scandinavian Economic History Review, vol. LI, 2003:1, 75-87.
} 
nart Sjöberg finds a similar lack of lingual provincialism as well as little improvement over time in internationalization for all of them except the last one. ${ }^{31}$ Altogether, the urge to write in local language could well explain much of the low rates of international publications.

c) Writing monographs: Examining all 68 Swedish dissertations in economic history finished in 2000-2004 reveals that 87\% were monographs (62\% in Swedish and 25\% in English) and 13\% article collections (3\% in Swedish and 10\% in English). Sjöberg found roughly the same numbers for three of his four analyzed behavioral sciences. ${ }^{32}$ Given the costs of transforming a monograph into separate articles (rewriting, rearranging) the observed numbers indicates another likely reason for the low rates of international publications of Swedish economic history.

d) Different method and theory approaches: Swedish economic history was founded by people from the history discipline, which strongly influenced the research approach and methodological focus on qualitative methods, inductive reasoning, source-criticism and so forth. ${ }^{33}$ Today the historical emphasis is evident in Swedish graduate programs in economic history with practically no training in quantitative and economic theoretical skills (apart from some course at the very basic level). ${ }^{34}$ This dominance emanated in the mid-century as the first professors of the field were themselves trained as historians and saw historical "source-criticism" as the most viable empirical approach. In the 1960's and 1970's, most Swedish economic historians accordingly dismissed the historical economics, or New Economic History, that Robert Fogel, Douglass North and others started in the U.S. with an emphasized use of economic modeling and econometric testing alongside the traditional qualitative and contextual historical approaches. Besides being critical against what was perceived as a "relaxed attitude to source-criticism", the Swedish resistance was perhaps most contingent on the strong Marxist currents influencing

\footnotetext{
${ }^{31}$ Sjöberg, Lennart "How international is Swedish behavioral science?", mimeo, Center for Risk Research, Stockholm School of Economics, 2004.

${ }^{32}$ Sjöberg finds that the share of monograph theses in Business Administration, Education and Sociology were $97 \%, 93 \%$ and $88 \%$, respectively (Sjöberg, How international is Swedish behavioral science?).

${ }^{33}$ This draws on Olsson, Fluctuat nec mergitur; Olsson, Ulf, Att skriva historia eller pröva teorier? Ett trettioårigt perspektiv på ekonomisk historia i Sverige, Kungl. Vitterhets och Antikvitetets Akademiens Arsbok 1995, Stockholm: Almqvist \& Wiksell International and Hettne, Björn, Ekonomisk historia i Sverige: En översikt av vetenskaplig produktion och forskningsinrkitning, Forskarutbildningen resultat, 1890-1975. UHÄ 1980

${ }^{34}$ The courses are listed in Utvärdering av ämnet ekonomisk historia, pp. 109ff.
} 
much of the field. The emancipatory ideologies have since the Marxist entry in the 1960 's been an integral part of Swedish economic history. ${ }^{35}$

The contrast with economic history in many other countries is stark, with much less obvious ideological preconceptions and different balances between economics and history. For example, in the U.S. and Canada the field has since decades been practically equivalent to economics, albeit with much of the context-based historical approaches retained. ${ }^{36}$ The situation in Europe is different with more equal balance between economics and history, although the Europeans publishing most actively in the "top-4" journals in recent years are clearly more of economists than historians. There are also other active strands in European economic history research, e.g., business history, but these scholars are more active in their own specific journals than in the general "top-4" journals. Regardless of the relative activities, however, it is my personal view that many in the younger generations of European economic historians are today increasingly requiring training in economics and quantitative skills.

There is hence a methodological discrepancy between Swedish and much of international economic history, but can it explain the low degree of Swedish international publications? The answer depends partly on which international journals one looks at. For example, in the social or business history journals the need for explicit economic reasoning and use of quantitative analyses may not be acute. Looking at the JEH, EEH, EHR, EREH and some other journals, however, the vast majority of the submitting authors must be able to at least read the historical economics literature, since this is what these journals mostly publish (but far from all the time!). The lack of individual data on journal submissions, acceptance rates and method use makes it unfeasible to fully explore this issue, but of the 8.33 Swedish papers published in the "top-4" journals the majority (6) clearly practices quantitative methods and most of them also explicitly relate to economic concepts.

\footnotetext{
${ }^{35}$ Some of these efforts are discussed by Olsson, Fluctuat nec mergitur, pp. 70, 75ff.

${ }^{36}$ See, e.g., Field, Alexander J. ed. The Future of Economic History, Amsterdam: Kluwer Nijhoff or Romer, Christina D., "The End of Economic History", Journal of Economic Education, vol. XXV, 1992:1, 49-66. An interesting critical view of the past tensions in U.S. economic history is given by Coclanis, Peter and David Carlton, "The Crisis in Economic History", Challenge, vol. XLIV, 2001:6, 93-103.
} 
Another piece of evidence is that preliminary comparisons across Swedish departments suggest a positive correlation between use of economic theory and quantitative analyses and publications of international journal articles and books. ${ }^{37}$ Somewhat surprising, Swedes does not seem to be overrepresented in social or business history journals (according to Tables 1 and 2 and section 3.3) despite the comparative advantage (in terms of interest, at least) relative to other countries. ${ }^{38}$ This finding actually suggests that the effect of methodology on publication behavior across methodologies is a non-linear one. Taken together, both the actual articles published and average output across departments with different method profiles indicates that Swedish economic historians practicing historical economics are more internationally integrated than those vested in other methods. Adding to this the strong dominance of Anglo-Saxon countries in journal publications and the dominance of economics within these countries, there are strong reasons to believe that the documented methodological wedge can explain much of the low Swedish international research output.

Against this background, it seems hard to motivate a continued one-sided methodological focus in Swedish graduate programs that train economic historians as pure historians often leaving them less knowledgeable in economics and statistics than the average undergraduate economist. This system disables them from critically reviewing any advanced quantitative analyses or detecting crucial statistical measurement errors in the writings of other economic historians, and how does this go together with the highly cherished practice of "source-criticism"? ${ }^{39}$ Recently some Swedish and Nordic economic historians have started to highlight some of these problems, e.g., Lars Magnusson criticizing the arguments underlying people's unwillingness to learn and use modern economic theory, and similarly Ola H. Grytten arguing for a more active use of quantitative methods alongside the already predominantly used qualitative techniques. ${ }^{40}$ Proposals to change the current graduate programs to incorporate more of "theory" and quantitative methods

\footnotetext{
37 This statement is based on comparing the output of Swedish higher faculty (same data as underlying Table 3), where the arguably most economics-oriented department, the one in Lund, is clearly above average for Sweden.

${ }^{38}$ For business history, this true only when the special issues of BH (especially the all-Swedish 1993 issue) is not counted. If they were, the representation is clearly above average as also shown in Table 2.

${ }^{39}$ Similar problems due to methodological one-sidedness are discussed in the case of economic geography by Sjöberg, Örjan and Fredrik Sjöholm, "Common ground? Prospects for integrating the economic geography of geographers and economists", Environment and Planning A, vol. XXXIV, 2002:3, 467-486.

${ }^{40}$ Magnusson, Lars "Between micro and macro - what economic history can learn from modern economics", Scandinavian Economic History Review, vol. LI, 2003:2, 14-22 and Grytten, Ola H. "Beyond quantitative and qualitative", Scandinavian Economic History Review, vol. LI, 2003:2, 23-32.
} 
have also been forwarded, but whether these attempts signal the start of a groundbreaking reform process or are merely advanced window-dressing remains to be seen. ${ }^{41}$

\section{Concluding remarks}

This paper has presented empirical evidence on the international research activities of Swedish economic historians. Contrary to the claims made by the recent national evaluation commission, the Swedish shares of international journal and book publications and conference presentations are clearly below available cross-country and cross-discipline benchmarks. These findings are robust to using either only non-invited or all articles as well as different time periods. When relating the output shares with available measures of research inputs (numbers of active scholars and size of funding) and comparing with foreign economic historians or scholars in other Swedish disciplines, the results are outright alarming as signals of a systematic underperformance and waste of resources.

The study also presents some explanations to these observed patterns. First, a relatively large supply of funding has made the Swedish field basically self-sufficient and almost independent of what is going on at the international arena. Second, there is a clear propensity to write in the local language, Swedish, which both makes it more difficult to submit papers to and signals a clear disinterest in international journals and conferences. Third, a majority of the researchers writes books instead of papers, as evidenced by the composition of dissertations in recent years, which also increases the costs of submissions to journals and conferences. Fourth, and finally, Swedish economic historians receive insufficient training in quantitative methods and economic theory which has made then both unable and probably less motivated to take active part in the scholarly work of foreign economic historians.

At a time when national research budgets are slashed and the competition for funding is sharpened, producing research on the international frontier becomes crucial. Some Swed-

\footnotetext{
${ }^{41}$ Lindgren, Håkan, Scandinavian business history at the end of the 1990s: its prior development, present situation and future, Business History around the World, Amatori, F. and Jones, G. (eds.), Cambridge: Cambridge University Press 2003. It should be noted that although Lindgren does not specify what he means by "theory" but it is probably not only referring to modern economic theory.
} 
ish economic historians already do this today. ${ }^{42}$ The established organizations and abundant research resources in place offer Swedish economic history a good chance to become internationally more productive and competitive. Without reformed graduate programs, urges to make people writing papers in English, and an increased use of historical economics, however, this development will not take place - as the historical evidence clearly shows.

\section{Acknowledgements}

I have received valuable comments from Anders Björklund, Jan Bohlin, Harald Edquist, Christer Gunnarsson, Magnus Henrekson, Lars Jonung, Sverre Knutsen, Håkan Lindgren, Kim Oosterlinck, Jan Ottosson, Karl Gunnar Persson, Jean-Laurent Rosenthal, Örjan Sjöberg, Hans Sjögren, Hans-Joachim Voth, Eugene White, Anders Ögren, two anonymous referees and seminar participants at Lund University and Stockholm School of Economics. This paper was partly written during my time as a Global Fellow at the UCLA International Institute. Financial support from the Jan Wallander and Tom Hedelius Foundation is also gratefully acknowledged.

\footnotetext{
${ }^{42}$ See, e.g., Allen, Robert C., Tommy Bengtsson and Martin Dribe (eds), Living Standards in the Past. New Perspectives on Well-Being in Asia and Europe, Oxford University Press, 2005 and the numerous volumes on historical accounts by Lennart Schön, Jonas Ljungberg, Olle Krantz and their colleagues.
} 


\section{APPENDIX: Nordic publications in economic history journals, 1970-2004.}

* denotes invited article in a special issue or debate article, $\mathrm{N}$ denotes (non-Swedish) Nordic authors and $\mathrm{S}$ Swedish scholars from other academic disciplines. Book reviews are excluded. For SEHR and EH, only authors at Swedish economic history departments are listed.

\section{Business History (1970-2004)}

N Knutsen, Sverre and Einar Lie, "Financial Fragility, Growth strategies and Banking Failures: The major Norwegian Banks and the Banking Crisis, 1987-92", vol. XLII, 2002:2, 88-111.

S Boldt-Christmas, Martin, Fagerland Jacobsen, Siv, Tschoegl, Adrian E., "The Internationals Expansion of the Norwegian Banks", vol. XLIII, 2001:3, 79-104.

N Hansen, Per H., "Bank Regulation in Denmark from to World War Two: Public Interests and Private Interests", vol. XLIII, 2001:1, 43-68.

* ("Special issue") Sjögren, Hans, "Financial Reconstruction and Industrial Reorganisation in Different Financial Systems: A Comparative View of British and Swedish Institutions during the Inter-War Period", vol. XXXIX, 1997:4, 84-105.

$\mathrm{N} *$ ("Special issue") Knutsen, Sverre, "Post-War Strategic Capitalism in Norway: A Theoretical and Analytical Framework", vol. XXXIX, 1997:4, 106-127.

N Amdam, Rolv Petter and Ove Bjarnar, "Regional Business Networks and the Diffusion of American Management and Organisational Models to Norway, 1945-65”, vol. XXXIX, 1997:1, 72-90.

* ("Special issue") Sjögren, Hans and Sven Jungerhem, "Small Firm Financing in Sweden, 1960-95", vol. XXXVIII, 1996:3, 27-47.

* ("Special issue") Ottosson, Jan and Anders Lundgren, "AB Gust Carlsson, 1880-1990: Networks and Survival in the Swedish Printing Industry”, vol. XXXVIII, 1996:3, 117-126.

N Amdam, Rolv Petter, "Foreign Influence on the Education of Norwegian Business Managers, before World War II", vol. XXXVI, 1996:4, 79-94.

* ("Special issue") Ullenhag, Kersti, "Introduction", vol. XXXV, 1993:2, 1-10.

* ("Special issue") Göransson, Anita, "Gender and Property Rights: Capital, Kin and Owner Influence in Nineteenth- and Twentieth-Century Sweden", vol. XXXV, 1993:2, 11-32.

* ("Special issue") Boje, Per, "A Career Approach to Entrepreneurship: The Case of Thomas B. Thrige", vol. XXXV, 1993:2, 33-44.

* ("Special issue") Anell, Barbro, "Timing is All: On the Roles of Owners and Managers in Expanding and Contracting Corporate Activities", vol. XXXV, 1993:2, 45-54.

* ("Special issue") Modig, Hans, "Management of Public Enterprises: A Special Type of Managerial Capitalism? The Swedish Case", vol. XXXV, 1993:2, 55-67.

* ("Special issue") Ullenhag, Kersti, "Those in Power: On the Role of Owners in Swedish Business", vol. XXXV, 1993:2, 68-86.

* ("Special issue") Johansson, Alf, "Structures, Managers and Owners: The Case of the Post-War Swedish Paint Industry", vol. XXXV, 1993:2, 87-98.

* ("Special issue”) Glete, Jan, "Swedish Managerial Capitalism: Did It Ever Become Ascendant?", vol. XXXV, 1993:2, 99-110.

* ("Special issue") Sjögren, Hans, "Long-Term Contracts in the Swedish Bank-Orientated Financial System during the Inter-War Period", vol. XXXIII, 1991:3, 119-137.

N * ("Special issue”) Møller, A. M., "Consular Reports: The Danish Monarchy, 1794-1904”, vol. XXIII, 1981:2, 276-278.

* ("Special issue") Högberg, Staffan, "Consular Reports to the Swedish Board of Trade”, vol. XXIII, 1981:2, 294-299.

\section{Economic History Review (1970-2004)}

Evans, Chris, Owen Jackson and Göran Rydén, "Baltic Iron and the British Iron Industry in the Eighteenth Century", vol. LV, 2002:4, 642-665.

N Hybel, Nils, "The Grain Trade in Northern Europe before 1350”, vol. LV, 2002:2, 219-247.

N Persson, Karl Gunnar, "The seven lean years, elasticity traps and intervention in grain markets in preindustrial Europe", vol. XLIX, 1996:4, 692-714.

N ("Notes and comments") Persson, Karl Gunnar, "Was there a productivity gap between fourteenthcentury Italy and England?”, vol. XLVI, 1993:1, 105-114.

N Johansen, Hans Chr., "Scandinavian shipping in the late eighteenth century in a European perspective", vol. XLV, 1992:3, 479-493.

Economy and History (1970-1980)

NB: The list only contains authors active at Swedish economic history departments! 
Schön, Lennart, "British competition and domestic change, Textiles in Sweden 1820-1870", vol. XXIII, 1980:1, 61-76.

Fridlizius, Gunnar, "Population, enclosure and property rights", vol. XXII, 1979:1, 3-37.

Gaunitz, Sven, "Local history as a means of understanding economic development. A study of the timber frontier in Northern Sweden during the industrialization period", vol. XXII, 1979:1, 38-62.

Ahlström, Göran, "Higher technical education and the engineering profession in France and Germany during the 19th century", vol. XXI, 1979:2, 51-88.

Nilsson, Carl-Axel and Lennart Schön, "Factories in Sweden 1820-1870. A typological approach", vol. XXI, 1979:2, 89-103.

Pettersson, Lars, "Some aspects of the expansion of education in Sweden", vol. XX, 1977:2, 69-91.

Nilsson, Anders, "Study financing and expansion of education. An empirical study of study financing of University students in Sweden 1920-1957”, vol. XX, 1977:2, 92-113.

Hatti, Neelambar, "Impact of assistance under PL 480 on Indian economy 1956-1970”, vol. XX, 1977:1, 23-40.

Krantz, Olle, "Production and labour in the Swedish manufactories during the 18th century", vol. XIX, 1976:2, 83-97.

* ("Discussion") Lindgren, Håkan, "Price development and economic policy in Sweden 1776-1802. A rejoinder to a rejoinder", vol. XIX, 1976:1, 142-143.

Krantz, Olle, "Production and labour in the Swedish manufactories during the 18th century", vol. XIX, 1976:1, 27-48.

Ahlström, Göran, "Price development and economic policy in Sweden 1776-1802. A rejoinder", vol. XIX, 1976:1, 66-69.

Bengtsson, Tommy, "Lennart Jörberg, Market integration in Sweden during the 18th and 19th centuries. Spectral analysis of grain prices", vol. XVIII, 1975:2, 93-104.

Fridlizius, Gunnar, "Some new aspects on Swedish population Growth. II. A study at Parish level”, vol. XVIII, 1975:2, 126-154.

Fridlizius, Gunnar, "Some new aspects on Swedish population growth", vol. XVIII, 1975:1, 3-33.

Olsson, Carl-Axel, "Estimates of the aggregate Swedish farm supply function 1935-1950. Some preliminary results", 17, 3-19.

Krantz, Olle and Carl-Axel Nilsson, "Relative income levels in the Scandinavian countries", XVII, 1974, 52-69.

Bengtsson, Tommy and Mats Johansson, "The contribution of the manufacturing industry to the GDP of Sweden: 1941-1951”, XVII, 1974, 70-92.

Persson, Gunnar, "Social mobility in Sweden 1925-1945”, XVII, 1974, 83-93.

Hatti, Neelambar, "A note on inflation and prices in India during 1939-45”, XVII, 1974, 94-105.

Hatti, Neelambar, "External assistance to India from Western governments and international agencies during 1951-61", XVI, 1973, 55-80.

Krantz, Olle, "The competition between railways and domestic shipping in Sweden 1870-1914", XVI, 1973, 19-40.

Jörberg, Lennart, "The development of real wages for agricultural workers in Sweden during the 18th and 19th centuries", XV, 1972, 41-57.

Schön, Lennart, "Västernorrland in the middle of the nineteenth century - a study in the transition from small-scale to capitalistic production", XV, 1972, 83-111.

Bjurling, Oscar, "Swedish shipping and British-Dutch competition during the 1670s and 1680s", XIV, 1971, 3-26.

Nilsson, Carl-Axel, "Some notes on the Swedish iron and steel consumption 1885-1914", XIV, 1971, 2753.

Järnek, Martin, "Swedish income distribution in the 1960's", XIV, 1971, 54-63.

Olsson, Carl-Axel, “The Cobb-Douglas or the Wicksell function?”, XIV, 1971, 64-69.

Ohlsson, Rolf, “Economic fluctuations and immigration to Sweden 1945-1967”, XIII, 1970, 3-23.

Hatti, Neelambar, "Growth of private foreign investments in India 1948-1960”, XIII, 1970, 54-?.

European Journal of the History of Economic Thought (1994-2004)

S Stenkula, Mikael, "Carl Menger and the Network Theory of Money", vol. X, 2003:4, 587-606.

Carlson, Benny, "The Institutional Ideas Virus - The Case of Johan Åkerman”, vol. VI, 1999:1, 71-86.

S Sandelin, Bo and Sinimaaria Ranki, "Internationalization or Americanization of Swedish economics?", vol. IV, 1997:2, 284-257.

Herlitz, Lars, "From spending and reproduction to circuit flow and equilibrium: the two conceptions of Tableau économique”, vol. III, 1996:1, 1-20. 
European Review of Economic History (1997-2004)

N Madsen, Jakob B., "Price and Wage Stickiness during the Great Depression", vol. VIII, 2004:3, 229262.

Kander, Astrid and Magnus Lindmark,, "Energy Consumption, Pollutant Emissions and Growth in the Long Run: Sweden through 200 years", vol. VIII, 2004:3, 297-335.

N Persson, Karl Gunnar, "Mind the Gap. Transport Costs and Price Convergence in the 19 Century Atlantic Economy", vol. VIII, 2004:2, 125-147.

N Grytten, Ola H.,, "A Norwegian Consumer Price Index 1819-in a Scandinavian Perspective”, 8(1), 6179.

Dribe, Martin, "Dealing with Economic Stress through Migration: Lesson from Nineteenth Century Rural Sweden", vol. VII, 2003:3, 271-300.

S Gustafsson, Björn and Mats Johansson, "Steps Toward Equality: How and Why Income Inequality in Urban Sweden Changed during the Period 1925-1958", vol. VII, 2003:2, 191-212.

Bohlin, Jan, "Swedish Historical National Accounts: The Fifth Generation", vol. VII, 2003:1, 73-98

N Falch, Torberg and Per Tovmo, "Norwegian local public finance in the 1930s and beyond", vol. VII, 2003:1, 127-154.

Lindmark, Magnus and Peter Vikström, "The Determinants of Structural Change: Transformation Pressure and Market Structure in Swedish Manufacturing Industry, 1870-1993", vol. VI, 2002:1, 87-110.

N Kaukiainen, Yriö,, "Shrinking the World: Improvements in the Speed of Information Transmission", vol. V, 2001:1, 1-28.

S Fregert, Klas, "The Great Depression in Sweden as a Wage Coordination Failure”, vol. IV, 2000:3, 341360.

* ("Special Issue") Schön, Lennart, "Electricity, Technological Change and Productivity in Swedish Industry, 1890-1990", vol. IV, 2000:2, 175-194.

Nilsson, Anders, Lars Pettersson and Patrick Svensson, "Agrarian Transition and Literacy: The Case of Nineteenth-Century Sweden", vol. III, 1999:1, 79-96.

N Henriksen, Ingrid, "Avoiding Lock-in: Cooperative Creameries in Denmark, 1882-1903", vol. III, 1999:1, 57-78.

N Klovland, Jan Tore, "Monetary Policy and Business Cycles in the Interwar Years: The Scandinavian Experience", vol. II, 1998:3, 309-344.

N Ojalá, Jari, "Approaching Europe: The Merchant Networks between Finland and Europe during the Eighteenth and Nineteenth Centuries", vol. I, 1997:3, 323-352.

\section{Explorations in Economic History (1970-2004)}

Lindmark, Magnus, "Patterns of historical CO2 intensity transitions among high and low-income countries", vol. XLI, 2004:4, 426-447.

S Waldenström, Daniel, "Taxing emerging stock markets: Beneficial or not? Evidence from the Stockholm Stock Exchange, 1907-1939”, vol. XXXIX, 2002:1, 29-45.

N Greasley, David, Jakob Brøchner Madsen and Les Oxley, "Income Uncertainty and Consumer Spending during the Great Depression", vol. XXXVIII, 2001:2, 225-251.

N Ejrnæs, Mette and Karl Gunnar Persson, "Market Integration and Transport Costs in France 1825-1903: A Threshold Error Correction Approach to the Law of One Price", vol. XXXVII, 2000:2, 149173.

N Eggertsson, Thraínn, "Sources of Risk, Instituions for Survival, and a Game against Nature in Premodern Iceland", vol. XXXV, 1998:1, 1-30.

S Lyttkens, Carl Hampus, "A Predatory Democracy - An Essay on Taxation in Classical Athens", vol. XXXI, 1994:1, 62-90.

N Klovland, Jan Tore, "Zooming in on Sauerbeck: Monthly Wholesale Prices in Britain 1845-1890”, vol. XXX, 1993:2, 195-228.

("Discussion") Söderberg, Johan, "Hard times in 19th-century Sweden: a comment", vol. XXVI, 1989:4, 477-491.

S Jonung, Lars, "Monetization and the behavior of velocity in Sweden, 1871-1913", vol. XXIV, 1983:4, $418-39$.

Financial History Review (1993-2004)

S Frey, Bruno S. and Daniel Waldenström, "Markets work in war: World War II reflected in the Zurich and Stockholm bond markets", vol. XI, 2004:1, 51-67.

S Waldenström, Daniel, "Why are securities transactions taxed? Evidence from Sweden, 1909-91", vol. IX, 2002:2, 169-194. 
Eigner, Peter, Margarita Dritsas and Jan Ottosson, "Big Business Networks in three Interwar Economies: Austria, Greece and Sweden”, vol. III, 1996:2, 175-195.

History of Political Economy (1987-2004)

S Siven, Claes-Henric and Heemeijer Heertje, "Samuelson on the Origin of Samuelson's MultiplierAccelerator Model”, vol. XXXV, 2003:2, 323-327.

Herlitz, Lars, "Wheat and Wood: Wicksell, Heckscher, and the Theory of Foreign Trade 1896-1920", vol. XXXIV, 2002:2, 449-478.

S Siven, Clase-Henric, “Analytical Foundations of Erik Lindahl's Monetary Analysis, 1924-1930”, vol. XXXIV, 2002:1, 111-153.

S Sandelin, Bo, "The De-Germanization of Swedish Economics", vol. XXXIII, 2001:3, 517-539.

$\mathrm{S} *$ Fridén, Bertil, "Problem of Unique Goods as Factors of Production: Rousseau on Art and the Economy”, vol. XXXI, 1999:(Annual supplement), 41-56.

Pålsson-Syll, Lars, "Myrdal's Immanent Critique of Utility Theory”, vol. XXX, 1998:3, 413-426.

$\mathrm{S} *$ Sandelin, Bo and Ann Veiderpass, "The Dissolution of the Swedish Tradition", vol. XXVII, 1996:(Annual supplement), 142-164.

S Sandelin, Bo, "The danger of approximation: Wicksell's Mistake on the Average Period of Investment", vol. XXII, 1990:3, 551-555.

S Jonung, Lars, "Knut Wicksell on Unemployment", History of Political Economy, vol. XXI, 1989:1, 2742.

S Sandelin, Bo, "Knight's Crusonia Plant - a Short Cut to the Wicksell Effect”, vol. XXI, 1989:1, 15-26.

Magnusson, Lars, "Mercantilism and Reform Mercantilism: The Rise Of Economic Discourse In Sweden during the Eighteenth Century", vol. XIX, 1987:3, 415-33.

N Kaergaard, Niels, "The Earliest History of Econometrics: Some Neglected Danish Contributions", vol. XVI, 1984:3, 437-445.

N Andersen, Peder, “'On Rent of Fishing Grounds' a Translation of Jens Warming's Article, with an Introduction", vol. XV, 1983:3, 391-397.

S Löfgren, Karl G., "The Faustmann-Ohlin Theorem: A Historical Note”, vol. XV, 1983:2, 261-265.

S Sandelin, Bo, “On Wicksell's Missing Equation: A Comment”, vol. XIV, 1982:3, 308-309.

N Langholm, Odd, "Economic Freedom in Scholastic Thought", vol. XIV, 1982:2, 260-284.

N Andvig, Jens Christopher, "Ragnar Frisch and Business Cycle Research during the Interwar Years", vol. XIII, 1981:4, 695-726.

N Bergh, Trond, "Norway: The Powerful Servants", vol. XIII, 1981:3, 471-513.

N Hansen, Bent, "Unemployment, Keynes, and the Stockholm School”, vol. XIII, 1981:2, 256-278.

S Ohlin, Bertil and Otto Steiger, "Stockholm and Cambridge: Four Papers on the Monetary and Employment Theory of the 1930s", vol. XIII, 1981:2, 189-255.

N Boserup, Mogens, “The International Transmission of Ideas: A Small-Country Case Study”, vol. XII, 1980:3, 420-434.

S Sandelin, Bo, "Wicksell's Missing Equation, the Production Function, and the Wicksell Effect", vol. XII, 1980:3, 29-40.

S Ohlin, Bertil, "On the Formulation of Monetary Theory", vol. X, 1978:3, 353-389.

S Sandelin, Bo, “The Wicksell Effect, Dewey and Others: A Note”, vol. VII, 1975:1, 123-131.

Journal of Economic History (1970-2004)

Lindgren, Håkan, "The Modernization of Swedish Credit Markets, 1840-1905: Evidence from Probate Records", vol. LXII, 2002:2, 810-832.

N Madsen, Jakob Brøchner, "Agricultural Crises and the International Transmission of the Great Depression", vol. LXI, 2001:2, 327-365.

N ("Notes and discussion") Ejrnæs, Mette and Karl Gunnar Persson, "Grain Storage in Early Modem Europe", vol. LIX, 1999:2, 762-772.

N Klovland, Jan Tore, "Pitfalls in the estimation of the yield on British consols, 1850-1914", vol. LXIV, 1994:1, 164-187.

\section{Journal of European Economic History (1972-2004)}

Lingärde, Svante and Andrew Tylecote, "Resource - Rich Countries Success and Failure in Technological Ascent, 1870-1970: the Nordic Countries versus Argentina, Uruguay and Brazil”, vol. XXVIII, 1999:1, 77-114.

Köll, Anu-Mai, "Peasants in the World Market: Dairy Cooperatives in Estonia, 1908-1936", vol. XXIII, 1994:3, 503-44. 
Söderberg, Johan, "Regional Economic Disparity and Dynamics, 1840-1914: A Comparison between France, Great Britain, Prussia and Sweden", vol. XIV, 1985:2, 273-96.

N Egge, Å, "Transformation of Bank Structures in the Industrial Period. The Case of Norway", vol. XXII, 1983:2, 271-291.

N Hansen, Svend Aage, "Transformation of Bank Structures in the Industrial Period: The Case of Denmark", vol. XI, 1982:3, 575-604.

Söderberg, Johan, "Causes of Poverty in Sweden in the Nineteenth Century”, vol. XI, 1982:2, 369-402.

S Carlsson, Sten, "The dissolution of the Swedish estates, 1700-1865”, vol. I, 1972:3, 574-624.

\section{Journal of the History of Economic Thought (1998-2004)}

Carlson, Benny, “Wagner's Swedish Students: Precursors on the Middle Way?”, vol. XXV, 2003:2, 437459.

Carlson, Benny, “Wagner's Legacy in America: Re-opening Farnam's Inquiry”, vol. XXI, 1999:3, 289310.

S ("Notes and Comments") Sandelin, Bo, "The Early Use of the Wicksell-Cobb-Douglas Function: A Comment on Weber", vol. XXI, 1999:2, 191-194.

\section{Labour History Review (1990-2004)}

S Hansson, Sven Ove, “'Socialism' in Sweden”, vol. LX, 1995:3, 37-39.

\section{Scandinavian Economic History Review (1970-2004)}

NB: The list only contains authors active at Swedish economic history departments!

* ("Special Issue) Karlsson, Birgit, "Neutrality and Free Trade: Sweden and Trade Liberalisation, 19481958", vol. LII, 2004:2-3, 39-61.

Lobell, Håkan, "Integration and Efficiency in the Foreign Exchange Market in Sweden 1834-1880", vol. LII, 2004:1, 7-18.

Palmer, Richard, "Variations in the Regional Distribution of Cross-Border Activity of Swedish Transnational Corporations during the 20th century", vol. XXXV, 1993:2, 7-27.

Müller, Leos, "The Swedish East India Trade and International Markets: Re-exports of Teas, 1731-1813", vol. LI, 2003:3, 28-43.

* ("Special Issue") Magnusson, Lars, "Between Micro and Macro - What Economic History Can Learn from Modern Economics", vol. LI, 2003:2, 14-22.

Dribe, Martin and Paul Nystedt, "Information, Trust and the Diffusion of Smallpox Vaccination: the Case of Scania in Sweden 1802-1835", vol. LI, 2003:1, 9-28.

Lindmark, Magnus and Peter Vikström, "Growth and structural change in Sweden and Finland, 18701990: a story of convergence”, vol. LI, 2003:1, 46-74.

Andersson-Skog, Lena and Olle Krantz, "Swedish Economic History Writing - National Self-Sufficiency or Recognition of the International Context?", vol. LI, 2003:1, 75-87.

* ("Special Issue") Krantz, Olle and Carl-Axel Nilsson, "Economy and History - A Dissident Journal", vol. L, 2002:3, 107-110.

Gratzer, Karl and Marcus Box, "Causes of Selection Amongst Swedish Firms: a Contribution to the Development of a Business Demography”, vol. L, 2002:1, 68-84.

Peterson, Christer, "Finnish Engineering and Swedish Imperialism: The Development Paths of Two Nordic Forest-Nations, 1950-1992", vol. IL, 2001:1, 23-40.

Söderberg, Johan, “Controversial Consumption in Sweden, 1914-1945”, vol. XLVIII, 2000:3, 5-21.

Krantz, Olle, "The Transport and Communications Sector in Economic Development: Views from the Historical National Accounts", vol. XLVIII, 2000:2, 5-29.

Andersson-Skog, Lena, "National Patterns in the Regulation of Railways and Telephony in the Nordic Countries to 1950", vol. XLVIII, 2000:2, 30-46.

Hedenborg, Susanna, "The World is Full of Sorrow: Infant Mortality in Stockholm, 1754-1850", vol. XLVIII, 2000:1, 64-80.

Pettersson, Lars, "The Swedish Model and Manufacturing Industry: A Pattern of Change", vol. XLVII, 1999:2, 45-62.

Jeding, Carl, Jan Ottosson and Lars Magnusson, "Regulatory Change and International Co-operation: The Scandinavian Telecommunication Agreements, 1900-1960", vol. XLVII, 1999:2, 63-77.

* ("Special Issue”) Knutsen, Sverre, Mary B. Rose and Hans Sjögren, “Introduction”, vol. XLVII, 1999:1, 5-9.

* ("Special Issue”) Sjögren, Hans, "Shipping as Gambling: Governance Mechanisms and the Bankruptcy of Saléninvest”, vol. XLVII, 1999:1, 48-64. 
Lundqvist, Torbjörn, "The Making of a National Cartel in the Swedish Brewing Industry, 1885-1908", vol. XLVI, 1998:2, 42-63.

Gustafsson, Bo, "Some Theoretical Problems of Institutional Economic History”, vol. XLVI, 1998:1, 531.

Sommestad, Lena, "Human Reproduction and the Rise of Welfare States: An Economic-Demographic Approach to Welfare State Formation in the United States and Sweden", vol. XLVI, 1998:1, 97-116.

* ("Special Issue") Söderberg, Johan and Lars Magnusson, "Introduction”, vol. XLVI, 1998:1, 7-10.

* ("Special Issue") Söderberg, Johan, "Consumption, Gender and Preferences in Sweden, 1920-1965", vol. XLVI, 1998:1, 71-84.

* ("Special Issue") Nyberg, Klas, Pernilla Jonsson, Mats Fagerberg and Erik Lindberg, "Trade and Marketing, Some Problems Concerning the Growth of Marker Institutions in Swedish Industrialisation", vol. XLVI, 1998:1, 85-102.

Schön, Lennart, “Internal and external Factors in Swedish Industrialization”, vol. XLV, 1997:3, 209-223.

Ljungberg, Jonas, "The Impact of the Great Emigration on the Swedish Economy", vol. XLV, 1997:2, 159-189.

Persson, Christer, "Land Ownership, Farm Structure and the Economy: Some Examples of Farm SubDivision in Sweden, 1780-1862", vol. XLV, 1997:1, 70-89.

Pettersson, Lars, "Reading and Writing Skills and the Agrarian Revolution: Scanian Peasants During the Age of Enclosure", vol. XLIV, 1996:3, 207-221.

Karlsson, Birgit, "Sweden and the OEEC, 1947-50: Walking the Tightrope", vol. XLIV, 1996:3, $222-243$.

* ("Discussion") Ljungberg, Jonas, "Catch-Up and Static Equilibrium: A Critique of the Convergence Model", vol. XLIV, 1996:3, 265-275.

Svensson, Lars, "Politics or Market Forces? The Determinants of the Relative Wage Movements of Female Industrial Workers in Sweden, 1960-1990", vol. XLIV, 1996:2, 161-182.

Andersson-Skog, Lena, "From State Railway Housekeeping, to Railway Economics: Swedish Railway Policy and Economic Transformation after in an Institutional Perspective", vol. XLIV, 1996:1, 23-42.

Olsson, Kent, "Big Business in Sweden: The Golden Age of the Great Swedish Ship-yards, 1945-1974", vol. XLIII, 1995:3, 310-338.

* ("Special Issue") Christensen, Jorgen Peter, Riitta Hjerppe, Olle Krantz and Carl-Axel Nilsson,, "Nordic Historical National Accounts since the 1880s", vol. XLIII, 1995:2, 30-52.

* ("Special Issue") Ohlsson, Rolf, "Introduction", vol. XLII, 1994:2, 123-124.

* ("Special Issue") Ohlsson, Rolf, "Demographic Aspects on the Labour Market Situation in Sweden during the Interwar Period”, vol. XLII, 1994:2, 187-199.

Carlén, Stefan, “An Institutional Analysis of the Swedish Salt Market, 1720-1862”, vol. XLII, 1994:1, 328.

Pålsson Syll, Lars, "Wicksell on Harmony Economics: The Lausanne School vs. Wicksell”, vol. XLI, 1993:2, 172-188.

* (“Discussion”) Krantz, Olle, “Are Data Unimportant in Business Cycle Analysis”, vol. XLI, 1993:2, 189-191.

Olsson, Carl-Axel, "Eli Heckscher and the Problem of Synthesis. A Methodological Note", vol. XL, 1992:3, 29-52.

Carlson, Benny, "Eli Heckscher and Natural Monopoly: The Nightmare that Never Came True", vol. XL, 1992:3, 53-79.

Pålsson-Syll, Lars, "Notes on Neoinstitutional Economics”, vol. XL, 1992:2, 21-33.

* ("Discussion") Ljungberg, Jonas, "Once More on the Gerschenkron Effect. A reply to Larsen and Nilsson", vol. XL, 1992:2, 54-58.

* ("Discussion") Ljungberg, Jonas, "When the Track does not Accord with the Map - A Critique of Rojas", vol. XL, 1992:2, 59-62.

* (“Special Issue”) Lindgren, Håkan, “Swedish Historical Research on Banking during the 1980's: Tradition and Renewal", vol. XXXIX, 1991:3, 5-19.

* ("Special Issue") Sjögren, Hans, "The Financial Contracts of Large Firms. A Longitudinal Study of Swedish Firms and Commercial Banks, 1919-1947”, vol. XXXIX, 1991:3, 72-94.

Carlson, Benny, “Gösta Bagge's American Lessons”, vol. XXXIX, 1991:2, 29-41.

Ljungberg, Jonas, "Prices and Industrial Transformation”, vol. XXXIX, 1991:2, 49-63.

* ("Discussion") Rojas, Mauricio, "The, "Swedish Model”, in Historical Perspective,", vol. XXXIX, 1991:2, 64-74.

Gunnarsson, Christer, "What is New and What is Institutional in the New Institutional Economics? An Essay on Old and New Institutionalism and the Role of the State in Developing Countries", vol. XXXIX, 1991:1, 43-67. 
Johansson, Alf and Joseph Melling," "Labour Relations and Industrial Productivity”, vol. XXXVIII, 1990:3, 22-43.

* ("Special Issue") Fridjonsdottir, Katrin and Bo Gustafsson, "Introduction", vol. XXXVIII, 1990:2, 3.

* ("Special Issue") Fridlizius, Gunnar, "The Growth of a Population Research Group in Economic History", vol. XXXVIII, 1990:2, 4-17.

* ("Special Issue") Gadd, Carl-Johan and Ulf Jonsson, "Agrarian History as a Sub-Field of Swedish Economic History", vol. XXXVIII, 1990:2, 18-30.

* ("Special Issue") Hildebrand, Karl-Gustaf, "Swedish Economic History before the 1980s", vol. XXXVIII, 1990:2, 31-40.

*(“Special Issue”) Krantz, Olle, "Macroeconomic History in Sweden”, vol. XXXVIII, 1990:2, 41-51.

* ("Special Issue") Magnusson, Lars, "Social History as Economic History in Sweden. Some Remarks", vol. XXXVIII, 1990:2, 52-57.

* ("Special Issue") Olsson, Ulf, "Business History as Economic History”, vol. XXXVIII, 1990:2, 59-64.

* ("Special Issue”) Wikander, Ulla, “On Women’s History and Economic History”, vol. XXXVIII, 1990:2, 65-71.

Gunnar Fridlizius, The Deformation of Cohorts: Nineteenth Century Mortality Decline in a Generational Perspective, vol. XXXVII, 1989:3, 3-17.

Herlitz, Lars, "On the Prehistory of the Trinity: Functional Class Division from Mercantilism to Classicism", vol. XXXVII, 1989:2, 5-25.

Karlsson, Per-Arne, "Housekeeping Ideology and Equilibrium Policy in Eighteenth Century Sweden”, vol. XXXVII, 1989:2, 51-77.

Magnusson, Lars, "Corruption and Civic Order. Natural Law and Economic Discourse in Sweden during the Age of Freedom", vol. XXXVII, 1989:2, 78-105.

* ("Special Issue") Adamson, Rolf, "Economic History Research in Sweden since the mid-1970s", vol. XXXVI, 1988:3, 51-66.

Olsson, Sven-Olof, "Swedish-Polish Trade Negotiations at the End of the Second World War and Their Results", vol. XXXVI, 1988:2, 30-41.

Söderberg, Johan and Arne Jansson, "Corn-Price Rises and Equalisation: Real Wages in Stockholm 16501719”, vol. XXXVI, 1988:2, 42-67.

Ullenhag, Kersti, "Firms under Expansion. A Theoretical Model and Its Application", vol. XXXVI, 1988:2, 68-81.

Carlson, Benny, "Lindahl Dynamics and Death", vol. XXXVI, 1988:1, 76-86.

Åström, Sven-Erik, "Northeastern Europe's Timber Trade Between The Napoleonic and Crimean Wars: A Preliminary Survey", vol. XXXV, 1987:2, 170-177.

Martinius, Sture, "Capitalism: A Threat Against Freehold Farms Around The Middle of Nineteenth Century?”, vol. XXXV, 1987:2, 178-190.

Gustafson, Bo, "The Rise and Economic Behaviour of Medieval Craft Guilds. An Economic-Theoretical Interpretation", vol. XXXV, 1987:1, 1-40.

Morell, Mats, "Eli F. Heckscher, The 'Food Budgets' and Swedish Food Consumption From The 16th to The 197h Century", vol. XXXV, 1987:1, 67-107.

* ("Special Issue") Olsson, Ulf, "Recent Research on Changes in the Standard of Living During the Eighteenth and Nineteenth Centuries", vol. XXXIV, 1986:2, 153-158.

Magnusson, Lars, "Drinking and the Verlag System 1820-1850: The Significance of Taverns and Drink in Eskilstuna before Industrialisation", vol. XXXIV, 1986:1, 1-19.

Pettersson, Lars, "Engineer Training in Sweden during the Postwar Period in the Context of Technical and Structural Change", vol. XXXIII, 1985:2, 108-121.

Söderberg, Johan, “A Long-Term Perspective on Regional Economic Development in Sweden, ca. 15501914”, vol. XXXII, 1984:1, 1-16.

Björklund, Jörgen, "From the Gulf of Bothnia to the White Sea", vol. XXXII, 1984:1, 17-41.

Krantz, Olle, "Historical National Accounts - some Methodological Notes", vol. XXXI, 1983:2, 109-131.

Lindgren, Håkan, "The Kreuger Crash of In Memory of a Financial Genius, or Was He a Simple Swindler?”, vol. XXX, 1982:3, 189-206.

Åström, Sven-Erik, "Swedish Iron and the English Iron Industry about 1700: Some Neglected Aspects", vol. XXX, 1982:2, 129-142.

* ("Special Issue”) Jörberg, Lennart, "Proto-Industrialisation - an Economic Historical Figment?", vol. XXX, 1982:1, 1-2.

* ("Special Issue") Schön, Lennart, "Proto-Industrialisation and Factories: Textiles in Sweden in the MidNineteenth Century", vol. XXX, 1982:1, 57-72.

* ("Special Issue") Magnusson, Lars and Maths Isacson, "Proto-Industrialisation in Sweden: Smithcraft in Eskilstuna and Southern Dalecarlia", vol. XXX, 1982:1, 73-99. 
Attman, Artur, “The Russian Market in World Trade, 1500-1860”, vol. XXIX, 1981:3, 177-202.

Hornby, Ove and Carl-Axel Nilsson, "The Transition from Sail to Steam in the Danish Merchant Fleet", vol. XXVIII, 1980:2, 109-134.

Fritz, Martin, "Shipping in Sweden”, vol. XXVIII, 1980:2, 147-160.

Morell, Mats, "On the Stratification of the Swedish Peasant Class", vol. XXVIII, 1980:1, 15-32.

* ("Discussion") Gadd, Carl-Johan, "Rejoinder to Sture Martinius on Peasant Destinies", vol. XXVII, 1979:2, 72-73.

* (“Discussion”) Martinius, Sture, “A Rejoinder to a Rejoinder about Peasant Destinies”, vol. XXVII, 1979:2, 73-74.

* ("Discussion") Martinius, Sture, "Reply to Carl-Johan Gadd's Review on Peasant Destinies", vol. XXVII, 1979:2, 166-168.

Magnusson, Lars, "Eli Heckscher, Mercantillism, and the Favourable Balance of Trade", vol. XXVI, 1978:2, 103-127.

* ("Discussion") Nilsson, Carl-Axel, "Foreign Trade and the Breakthrough of the Engineering Industry in Sweden; a comment", vol. XXVI, 1978:2, 156-163.

Kuuse, Jan, "Foreign Trade and the Breakthrough of the Engineering Industry in Sweden 1890-1920", vol. XXV, 1977:1, 1-36.

Olsson, Sven-Olof, “The documents of 'Zentrale Planung' as a basis for research on the German war economy", vol. XXIV, 1976:1, 45-59.

Hildebrand, Karl-Gustaf, "Economic Policy in Scandinavia during the interwar period", vol. XXIII, 1975:2, 99-115.

Åström, Sven-Erik, "Technology and timber exports from the Gulf of Finland, 1661-1740", vol. XXIII, 1975:1, 1-14.

Fritz, Martin, "Swedish Ball-Bearings and The German War Economy”, vol. XXIII, 1975:1, 15-35.

Olsson, Kent, "Methods and Sources for the Study of Swedish Standards of Living", vol. XXII, 1974:2, 136-151.

Kuuse, Jan, "The probate inventory as a source for economic and social history", vol. XXII, 1974:1, 2231.

Fritz, Martin, “Swedish Iron Ore and German Steel 1939-40”, vol. XXI, 1973:2, 133-144.

Fagerberg, Bengt, "The Transfer of Peasant Forest to Sawmill Companies in Northern Sweden", vol. XXI, 1973:2, 164-191.

* ("Discussion") Jörberg, Lennart, "The Industrial Revolution in Norway", vol. XX, 1972:2, 165-170.

Kuuse, Jan, "Mechanisation, Commercialisation and the Protectionist Movement in Swedish Agriculture", vol. XIX, 1971:1, 23-44.

Åström, Sven-Erik, "English Timber Imports from Northern Europe in the Eighteenth Century”, vol. XVIII, 1970:1, 12-32. 
Table 1. Articles by Swedes in international economic history journals, 1970-2004

\begin{tabular}{|c|c|c|c|c|c|c|c|c|c|c|c|c|c|c|}
\hline \multirow[b]{2}{*}{ Journal name } & \multirow{2}{*}{$\begin{array}{l}\text { Longer } \\
\text { period }\end{array}$} & \multicolumn{3}{|c|}{ Excl. special issues } & \multicolumn{3}{|c|}{ Incl. special issues } & \multirow{2}{*}{$\begin{array}{l}\text { Recent } \\
\text { period }\end{array}$} & \multicolumn{3}{|c|}{ Excl. special issues } & \multicolumn{3}{|c|}{ Incl. special issues } \\
\hline & & Total & Swedish & $\%$ & Total & Swedish & $\%$ & & Total & Swedish & $\%$ & Total & Swedish & $\%$ \\
\hline Journal of Economic History & $1970-2004$ & 1869 & 1 & 0.1 & 1873 & 1 & 0.1 & $1998-2004$ & 334 & 1 & 0.3 & 338 & 1 & 0.3 \\
\hline Explorations in Economic History & $1970-2004$ & 730 & 2 & 0.3 & 730 & 2 & 0.3 & 1998-2004 & 124 & 1 & 0.8 & 124 & 1 & 0.8 \\
\hline Economic History Review & $1970-2004$ & 1155 & 0.33 & 0.0 & 1155 & 0.33 & 0.0 & 1998-2004 & 125 & 0.33 & 0.3 & 125 & 0.33 & 0.3 \\
\hline European Review of Economic History & $1997-2004$ & 113 & 5 & 4.4 & 102 & 6 & 5.9 & 1998-2004 & 101 & 5 & 5.0 & 90 & 6 & 6.7 \\
\hline Sum "top-4" & & 3867 & 8.33 & 0.22 & 3860 & 9.33 & 0.24 & & 684 & 7.33 & 1.07 & 677 & 8.33 & 1.23 \\
\hline Accounting, Business \& Financial History & $1990-2004$ & 142 & 0 & 0.0 & 218 & 0 & 0.0 & 1998-2004 & 69 & 0 & 0.0 & 103 & 0 & 0.0 \\
\hline Business History & $1970-2004$ & 478 & 0 & 0.0 & 666 & 13 & 2.0 & $1998-2004$ & 131 & 0 & 0.0 & 166 & 0 & 0.0 \\
\hline Business History Review & $1970-2004$ & 536 & 0 & 0.0 & 604 & 0 & 0.0 & $1998-2004$ & 91 & 0 & 0.0 & 102 & 0 & 0.0 \\
\hline Economy and History $(\mathrm{EH})$ & $1970-1980$ & 70 & 29 & 41.4 & 70 & 29 & 41.4 & & & & & & & \\
\hline Enterprise \& Society & $2000-2004$ & 73 & 0 & 0.0 & 73 & 0 & 0.0 & $1998-2004$ & 73 & 0 & 0.0 & 73 & 0 & 0.0 \\
\hline $\begin{array}{l}\text { European Journal of the History of Eco- } \\
\text { nomic Thought }\end{array}$ & 1994-2004 & 213 & 2 & 0.9 & 244 & 2 & 0.8 & 1998-2004 & 136 & 1 & 0.7 & 136 & 1 & 0.7 \\
\hline Financial History Review & $1993-2004$ & 96 & 0.33 & 0.3 & 96 & 0.33 & 0.3 & $1998-2004$ & 56 & 0 & 0.0 & 56 & 0 & 0.0 \\
\hline History of Economic Ideas & 1993-2004 & 162 & 0 & 0.0 & 246 & 0 & 0.0 & 1998-2004 & 98 & 0 & 0.0 & 131 & 0 & 0.0 \\
\hline History of Political Economy & $1970-2004$ & 852 & 3 & 0.4 & 1041 & 3 & 0.3 & $1998-2004$ & 103 & 2 & 1.9 & 217 & 2 & 0.9 \\
\hline Journal of European Economic History & $1972-2004$ & 873 & 3.5 & 0.4 & 881 & 3.5 & 0.4 & $1998-2004$ & 112 & 0.5 & 0.4 & 120 & 0.5 & 0.4 \\
\hline Journal of the History of Economic Thought & $1998-2004$ & 181 & 2 & 1.1 & 181 & 2 & 1.1 & 1998-2004 & 181 & 2 & 1.1 & 181 & 2 & 1.1 \\
\hline Journal of Transport History & $1971-2004$ & 265 & 0 & 0.0 & 306 & 0 & 0.0 & $1998-2004$ & 50 & 0 & 0.0 & 57 & 0 & 0.0 \\
\hline Labour History Review & 1998-2004 & 101 & 0 & 0.0 & 101 & 0 & 0.0 & 1998-2004 & 101 & 0 & 0.0 & 101 & 0 & 0.0 \\
\hline $\begin{array}{l}\text { Scandinavian Economic History Review } \\
\text { (SEHR) }\end{array}$ & $1970-2004$ & 596 & 70 & 11.7 & 675 & 70 & 10.4 & $1998-2004$ & 142 & 17 & 12.0 & 173 & 17 & 9.8 \\
\hline Sum other 14 & & 4638 & 109.83 & 2.37 & 5402 & 122.83 & 2.27 & & 1343 & 22.5 & 1.68 & 1616 & 22.5 & 1.39 \\
\hline Sum other 12 (excluding SEHR and EH) & & 3830 & 10.83 & 0.28 & 4439 & 23.83 & 0.54 & & 1132 & 5.5 & 0.49 & 1340 & 5.5 & 0.41 \\
\hline Total sum & & 8505 & 118.16 & 1.39 & 9262 & 132.16 & 1.43 & & 2027 & 29.83 & 1.47 & 2293 & 30.83 & 1.34 \\
\hline Total sum (excluding SEHR and EH) & & 7697 & 19.16 & 0.25 & 8299 & 33.16 & 0.40 & & 1816 & 12.83 & 0.71 & 2017 & 13.83 & 0.69 \\
\hline
\end{tabular}

Notes and sources: Swe = authors active at Swedish economic history departments. In some cases, the total number of articles was approximated and could marginally deviate from the true number. Also note that some journals have a censored time period due to lacking data availability. For sources see the text. The information in the table was last updated on March 2, 2005. 
Table 2. Numbers and shares of articles in the "top-4" economic history journals and two business history journals across countries, 1986-2004

\begin{tabular}{|c|c|c|c|c|c|c|c|c|c|c|c|c|c|c|}
\hline Country & $J E H$ & $\%$ & $E E H$ & $\%$ & $E H R$ & $\%$ & EREH & $\%$ & $B H R$ & $\%$ & $B H$ & $\%$ & All & $\%$ \\
\hline USA & 506 & 76.1 & 219 & 59.5 & 62 & 13.8 & 22 & 23.9 & 161 & 70.3 & 37 & 9.6 & 1007 & 46.0 \\
\hline UK & 58 & 8.7 & 56 & 15.2 & 293 & 65.3 & 14 & 15.2 & 27 & 11.8 & 238 & 62.0 & 686 & 31.4 \\
\hline Canada & 50 & 7.5 & 53 & 14.4 & 20 & 4.5 & 5 & 5.4 & 10 & 4.4 & 10 & 2.6 & 148 & 6.8 \\
\hline Australia & 11 & 1.7 & 16 & 4.3 & 28 & 6.2 & 2 & 2.2 & 5 & 2.2 & 23 & 6.0 & 85 & 3.9 \\
\hline Germany & 2 & 0.3 & 5 & 1.4 & 6 & 1.3 & 10 & 10.9 & 2 & 0.9 & 12 & 3.1 & 37 & 1.7 \\
\hline Spain & 9 & 1.4 & 3 & 0.8 & 12 & 2.7 & 4 & 4.3 & 1 & 0.4 & 6 & 1.6 & 35 & 1.6 \\
\hline Ireland & 8 & 1.2 & 7 & 1.9 & 8 & 1.8 & 5 & 5.4 & 0 & 0.0 & 4 & 1.0 & 32 & 1.5 \\
\hline Netherlands & 7 & 1.1 & 3 & 0.8 & 5 & 1.1 & 3 & 3.3 & 2 & 0.9 & 9 & 2.3 & 29 & 1.3 \\
\hline France & 8 & 1.2 & 8 & 2.2 & 6 & 1.3 & 2 & 2.2 & 2 & 0.9 & 1 & 0.3 & 27 & 1.2 \\
\hline Japan & 4 & 0.6 & 1 & 0.3 & 4 & 0.9 & 0 & 0.0 & 2 & 0.9 & 13 & 3.4 & 24 & 1.1 \\
\hline Italy & 5 & 0.8 & 7 & 1.9 & 4 & 0.9 & 4 & 4.3 & 1 & 0.4 & 2 & 0.5 & 23 & 1.1 \\
\hline Japan & 4 & 0.6 & 1 & 0.3 & 4 & 0.9 & 0 & 0.0 & 2 & 0.9 & 13 & 3.4 & 24 & 1.1 \\
\hline Sweden & 1 & 0.2 & 1 & 0.3 & 1 & 0.2 & 6 & 6.5 & 0 & 0.0 & 11 & 2.9 & 20 & 0.9 \\
\hline Denmark & 1 & 0.2 & 1 & 0.3 & 4 & 0.9 & 2 & 2.2 & 1 & 0.4 & 2 & 0.5 & 11 & 0.5 \\
\hline Norway & 1 & 0.2 & 1 & 0.3 & 0 & 0.0 & 2 & 2.2 & 0 & 0.0 & 4 & 1.0 & 8 & 0.4 \\
\hline Switzerland & 1 & 0.2 & 1 & 0.3 & 1 & 0.2 & 1 & 1.1 & 1 & 0.4 & 2 & 0.5 & 7 & 0.3 \\
\hline Portugal & 0 & 0.0 & 1 & 0.3 & 3 & 0.7 & 2 & 2.2 & 0 & 0.0 & 0 & 0.0 & 6 & 0.3 \\
\hline Belgium & 1 & 0.2 & 1 & 0.3 & 2 & 0.4 & 1 & 1.1 & 0 & 0.0 & 0 & 0.0 & 5 & 0.2 \\
\hline Finland & 0 & 0.0 & 0 & 0.0 & 0 & 0.0 & 2 & 2.2 & 0 & 0.0 & 1 & 0.3 & 3 & 0.1 \\
\hline Iceland & 0 & 0.0 & 1 & 0.3 & 0 & 0.0 & 0 & 0.0 & 0 & 0.0 & 0 & 0.0 & 1 & 0.0 \\
\hline India & 1 & 0.2 & 0 & 0.0 & 3 & 0.7 & 0 & 0.0 & 0 & 0.0 & 0 & 0.0 & 1 & 0.0 \\
\hline All articles & 665 & & 368 & & 449 & & 92 & & 229 & & 384 & & 2187 & \\
\hline
\end{tabular}

Notes and sources: Except for the bottom row ("All articles), the numbers in this table are not corrected for co-authorship. Sources are Social Sciences Citation Index (SSCI) for JEH, EEH, HER, BHR and BH and own calculations for EREH (everything as of 2005-03-02). 
Table 3: Internationally published books, book chapters and journal articles by Swedish professors and associate professors of economic history.

\begin{tabular}{|c|c|c|c|c|c|}
\hline & Sum & Mean & Median & $\operatorname{Max}(N)$ & $\operatorname{Min}(N)$ \\
\hline \multicolumn{6}{|l|}{ 1. Books (not edited) } \\
\hline a) Ranked international & 1.66 & 0.04 & 0 & $1(1)$ & $0(37)$ \\
\hline b) Other international & 5 & 0.13 & 0 & $2(1)$ & $0(36)$ \\
\hline c) Swedish & 4 & 0.10 & 0 & $1(4)$ & $0(36)$ \\
\hline \multicolumn{6}{|l|}{ 2. Chapters in books } \\
\hline a) Ranked international & 55.83 & 1.40 & 0.25 & $13.5(1)$ & $0(20)$ \\
\hline b) Other international & 48.16 & 1.20 & 1 & $5(1)$ & $0(15)$ \\
\hline c) Swedish & 11.83 & 0.30 & 0 & $2.33(1)$ & $0(32)$ \\
\hline \multicolumn{6}{|l|}{ Articles: } \\
\hline 3. Any international journal (non-econ. history) & 36.16 & 0.90 & 0.17 & $5.5(1)$ & $0(20)$ \\
\hline 4. Scandinavian journals (SEHR and EH) & 46.33 & 1.17 & 1 & $5(1)$ & $0(18)$ \\
\hline 5. International economic history journals & 11.33 & 0.28 & 0 & $3(1)$ & $0(32)$ \\
\hline Sum of $1,2,3,4$ and 5 & 223.3 & 5.52 & 4.25 & 22.83 & $0(4)$ \\
\hline No. of articles $(3+4+5)$ per year as Ph.D. & & 0.14 & 0.11 & 0.88 & $0(10)$ \\
\hline No. of publications $(1+2+3+4+5)$ per year as Ph.D. & & 0.34 & 0.21 & 1.96 & $0(4)$ \\
\hline \multicolumn{6}{|c|}{$\begin{array}{l}\text { Note and sources: The total number of professors }(23) \text { and associate professors (17) is } 40 . \operatorname{Max}(N) \text { and } \\
\operatorname{Min}(N) \text { denotes the number of scholars with the highest and lowest amount of publications in each cate- } \\
\text { gory. The bottom row is calculated by adding together each individual's own statistic. All figures are co- } \\
\text { authorship corrected and forthcoming publications are included when reported. See text for classification } \\
\text { details. All information comes from personal homepages, Econlit, SSCI and LIBRIS as of 2005-03-02 and } \\
\text { is available from the author upon request. }\end{array}$} \\
\hline
\end{tabular}


Table 4. Nationality of presenters at international economic history conferences

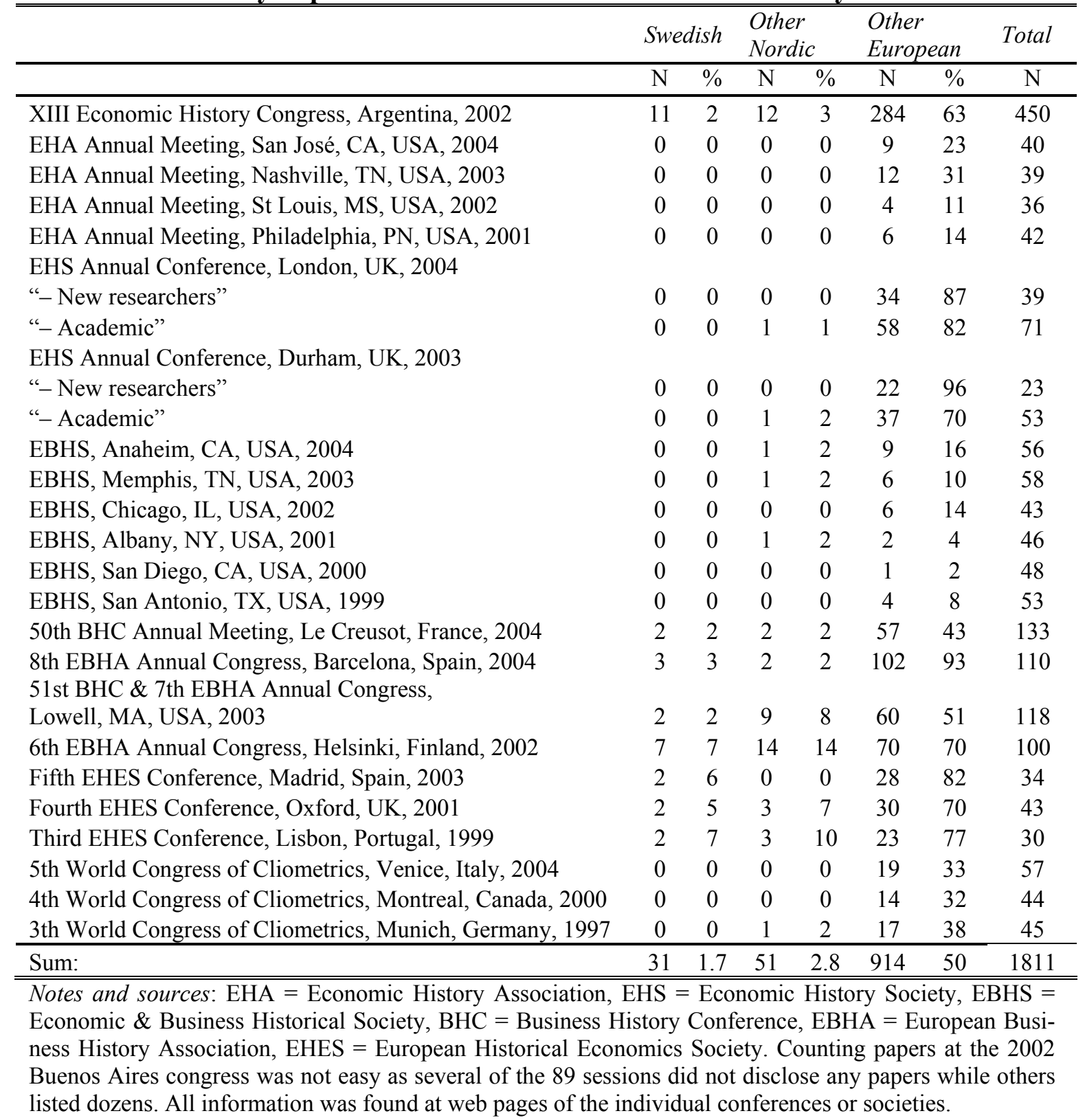


Table 5. English-written dissertations in economic history and economics at Swedish universities, 1970-2004 (numbers and shares of total)

\begin{tabular}{|c|c|c|c|c|}
\hline & $1970-79$ & 1980-94 & $1995-2004$ & Ongoing 2003 \\
\hline \multicolumn{5}{|l|}{ Economic History } \\
\hline Gothenburg & 1 of $12(8 \%)$ & 3 of $15(20 \%)$ & 1 of $18(6 \%)$ & 3 of $11(27 \%)$ \\
\hline Lund & 7 of $17(41 \%)$ & 10 of $20(50 \%)$ & 20 of $31(65 \%)$ & 10 of $32(31 \%)$ \\
\hline Stockholm & 1 of $4(25 \%)$ & 1 of $12(8 \%)$ & 3 of $19(16 \%)$ & 8 of $27(30 \%)$ \\
\hline Umeå & 0 of $2(0 \%)$ & 0 of $13(0 \%)$ & 3 of $11(27 \%)$ & 4 of $14(29 \%)$ \\
\hline Uppsala & 1 of $13(8 \%)$ & 1 of $13(8 \%)$ & 8 of $35(23 \%)$ & 3 of $33(9 \%)$ \\
\hline All economic history & 10 of $48(21 \%)$ & 15 of $73(21 \%)$ & 33 of $114(31 \%)$ & 28 of $117(24 \%)$ \\
\hline \multicolumn{5}{|l|}{ Economics } \\
\hline Gothenburg & 2 of $2(100 \%)$ & 40 of $50(80 \%)$ & 81 of $82(99 \%)$ & \\
\hline Lund & 7 of $13(54 \%)$ & 31 of $38(82 \%)$ & 64 of $64(100 \%)$ & \\
\hline Stockholm & 12 of $19(63 \%)$ & 41 of $44(93 \%)$ & 64 of $64(100 \%)$ & \\
\hline Umeå & 0 of $4(0 \%)$ & 19 of $28(68 \%)$ & 23 of $23(100 \%)$ & \\
\hline Uppsala & 3 of $6(50 \%)$ & 45 of $38(92 \%)$ & 61 of $61(100 \%)$ & \\
\hline All economics & 24 of $44(55 \%)$ & 176 of $198(89 \%)$ & 286 of $287(100 \%)$ & \\
\hline
\end{tabular}

Sources: Departmental web pages and LIBRIS (for economic history in Stockholm), as of March 2, 2005. For ongoing projects, see Evaluation commission (2003, pp. 113ff). 
Figure 1. Articles in top-4 journals by Swedish economic historians, 1970-2004

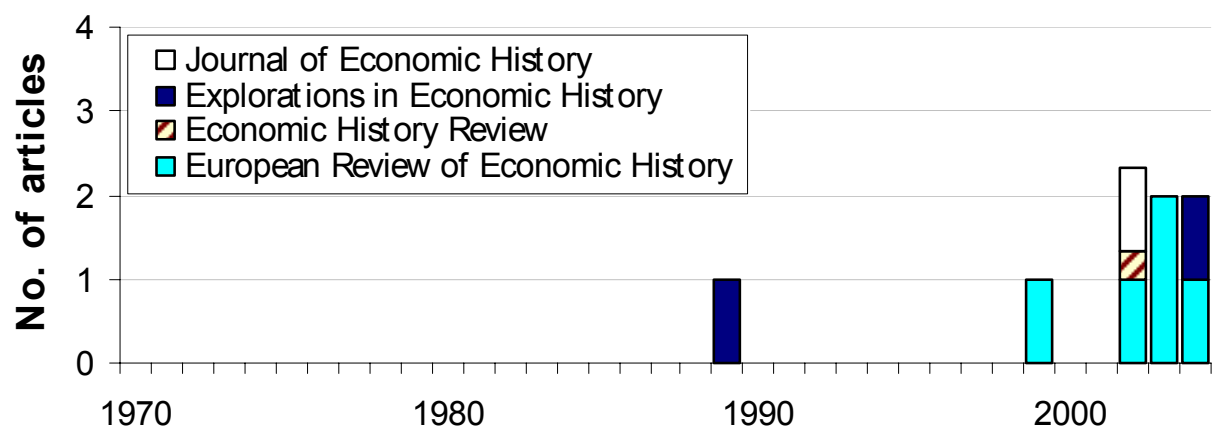

Note: Only non-invited articles are included.

Figure 2. Articles in top-4 journals by other Nordic economic historians, 1970-2004

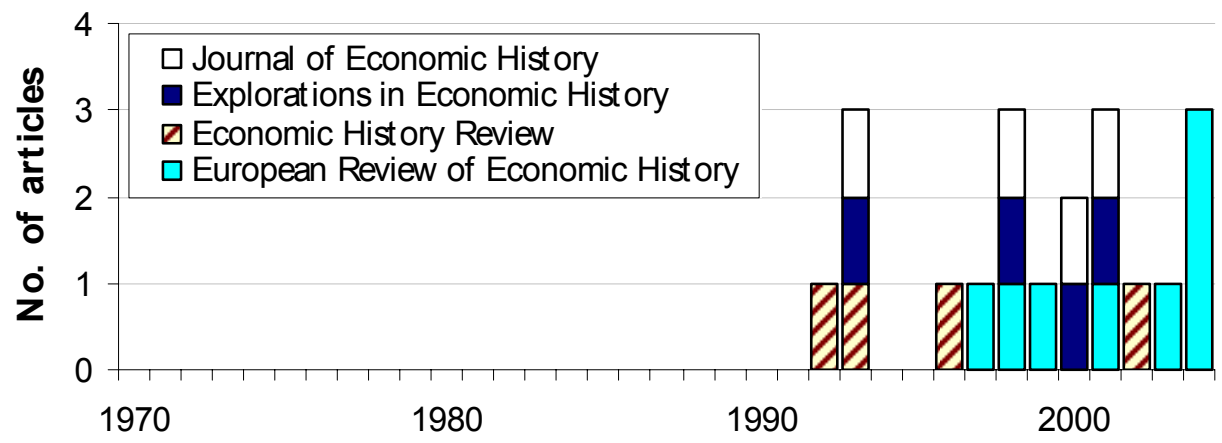

Note: The "other Nordic" countries are Denmark, Finland, Norway and Iceland. Only non-invited articles are included 